\title{
Revealing Intercultural Communicative Competence in an EFL High School Textbook
}

\author{
Ali Rosyidi \\ Department of English Education and Literature \\ Postgraduate School of State University of Surabaya \\ Surabaya, Indonesia \\ alirosyidi@mhs.unesa.ac.id
}

\author{
Oikurema Purwati \\ Department of English Education and Literature \\ Postgraduate School of State University of Surabaya \\ Surabaya, Indonesia \\ oikuremapurwati@unesa.ac.id
}

\begin{abstract}
Since the goal of teaching English is now shifted from communicative competence to intercultural communicative competence (ICC), English teachers should rethink of and be selective on using teaching sources which are mainly referred to textbooks. Many studies were then conducted to analyze the cultural contents in EFL textbooks in Asia whether they meet global goals in ELT. Analyzing textbook contents is now significantly needed by English teachers because of the trend movement in ELT. They should correspond the teaching materials to the notion of ICC in the in-use textbooks. In Indonesia, government has already recommended the English textbooks used at schools. One of them is Bahasa Inggris for the tenth graders. With respect to cultural teaching, English teachers are reluctant to employ the textbook in the classroom. Therefore, this present paper tries (1) to reveal to what extent the learning tasks in Bahasa Inggris contain intercultural competence and (2) to identify what components of intercultural competence are embedded in the textbook learning tasks. This study employs the model of ICC proposed by Byram. The findings show that very small extent learning tasks encourage students' intercultural competence. Yet, communicative competence is much promoted.
\end{abstract}

Keywords-Intercultural Communicative Competence,
LearningTasks, and Textbook

\section{INTRODUCTION}

The trend development of English Language Teaching (ELT) is now shifted from communicative competence to intercultural communicative competence as stated by $\mathrm{Fu}$ in Xiao [1]. It is also supported through many studies which are concerned on intercultural competence-based teaching in Asia such as Cheng (2007) in Taiwan, Han and Song (2009) in China, Baker (2009) in Thailand, Ishii (2009) in Japan, Zhou (2011) in China, Ho (2011) in Vietnam, Tian (2013) in China, $\mathrm{Gu}$ (2015) in China. Those all studies are well summarized and portrayed by Siregar [2].

Addressing intercultural communicative competence is very important in English language classroom especially in Indonesia since English is nowadays used by many kinds of people around the world for many purposes. Kachru (1985) categorized English users into three elements. They are inner circle, outer circle, and expanding circle. Inner circle refers to
UK, US, Canada, and Australia. This circle is the bases of English in traditional culture and language. Outer circle refers to India, Singapore, Malaysia, and Kenya for instance. This circle uses English as second language and has subsequently imposed English into educational, institutional, literary, and governmental sectors. Expanding circle refers to China, Japan, and Indonesia for instance. This circle uses English as foreign language. The people in this circle learns English for specific purposes such as doing business, accessing technology, proceeding academic needs [3].

To promote intercultural communicative competence in the classroom, English teachers can employ some teaching sources such as textbook, computer, radio, cassette, VCD, magazine, or newspaper. Sercu argues that the acquisition of intercultural communicative competence can be gained through increasing one's familiarity with foreign cultures, with one's own culture and with the relationships between cultures [4]. Thus, teachers should employ various teaching sources to address cultural knowledge to students. However, teachers mostly use textbook as the main teaching sources. This is in line with Richard that some teachers are using instructional materials - textbook - as the primary teaching learning sources in the classroom [5]. It is because textbooks are effective, practical, and portable. Kaisar reckons that textbooks are practically employed as a didactic instrument in teaching institutions [6]. It shows that textbook has great role in the teaching learning process. Thus, the instructional materials or textbooks determine a lot towards the acquisition of students' intercultural communicative competence.

The acquisition of intercultural communicative competence can be derived from learning tasks or activities in the textbook because they are set up to build particular language competence. Tomalin and Stempleski strongly advocated the use of task-oriented approach towards teaching cultures [7]. They believe that "studying culture with a taskoriented and cooperative learning approach adds a new dimension of achievement and understanding for the students". In addition, Edwards and Willis proposed the use of tasks in the language teaching as they can provide better context for activating learners' acquisition process and promoting second language learning [8]. It then leads teachers 
to choose the best textbook and evaluate more the materials and learning tasks which are provided in the textbook before using them in the classroom. Teachers are expected to acknowledge the components of intercultural communicative competence.

However, the government has already recommended the English textbooks which should be used in the classroom regarding the implementation of 2013 curriculum. The titles of the textbooks are When English Rings a Bell and Think Globally Act Locally for junior high students and Bahasa Inggris for senior high students. Some of schools in Gresik are using the textbooks as the learning sources, including SMAN 1 Gresik and SMAN 1 Manyar. The English teachers should employ the recommended textbook by the government, Bahasa Inggris, for tenth graders. Kjartansson and Skopinskaja argues that textbooks in foreign language instruction are mainly set up to facilitate language learning [9]. However, it is rather hard to employ it since language learning should be embedded with cultural contexts. This then leads to researcher curiosity to investigate whether the learning materials performed in the recommended textbook meet the notion of intercultural communicative competence.

Based on the previous studies above, cultural studiesresearches investigating cultural practices, values, systems, beliefs, and other aspects of cultures in the domain of teaching learning process including learning tasks presented in textbook-take important role in educational domain nowadays. Therefore, this study is conducted on the framework of cultural study which is aimed at investigating the learning tasks presented in the textbook entitled Bahasa Inggris for the tenth graders which is released by the Ministry of Education and Culture of Indonesia.

\section{METHODOLOGY}

\section{A. Research design}

This study was outlined and developed into a content analysis. It is a qualitative research. The first research question of this study is aimed at investigating to what extent the textbook learning tasks promote intercultural communicative competence. First, all chapters in the textbook will be looked up to identify the learning tasks. Second, those learning tasks will be categorized into communicative competence, intercultural competence, or non-intercultural communicative competence (neither communicative competence nor intercultural competence) by using checklist 1 generated from the model of communicative competence proposed by Murcia (2007) and intercultural competence proposed by Byram (1997). Afterwards, the second research question is aimed at revealing what components of intercultural competence are covered in the textbook learning tasks. Checklist 2 will be used to identify and classify the learning tasks based on the components of intercultural competence proposed by Byram (1997).

\section{B. Data of the study}

The data of this study were taken from the tenth grade textbook entitled Bahasa Inggris. This textbook was published in 2014 and was revised in 2016 by Ministry of Education and Culture of Indonesia. This textbook was chosen because it was recommended by government and was mostly used at public schools on the secondary level in Indonesia. The revised edition would be employed in this study. The authors of this textbook are Utami Widiati, Zuliati Rohmah, and Furaidah. It was launched for the need of 2013 curriculum. This textbook consists of 15 chapters. They are Talking about self, Congratulating and Complementing Others, Expressing Intention, Which One is Your Best Gateway, Let's Visit Niagara Falls, Giving Announcement, The Wright Brothers, My Idol, The Battle of Surabaya, B.J. Habibie, Cut Nyak Dien, Issumboshi, Malin Kundang, Strong Wind, and You've Got a Friend. However, this study is focused on the learning tasks which address the issue of intercultural communicative competence.

\section{Instrumentation}

The instruments used in this study were checklists and questionnaire [10]. To answer the first and second research questions in this study, checklists were employed. It is generated from communicative competence model proposed by Murcia (2007) and intercultural competence model which was proposed by Byram (1997). Murcia's communicative competence model was chosen because it is the latest model and used to develop English language materials while Byram's model of intercultural competence was chosen because it is the most compatible in English language teaching as stated by CEFR [11] and Deardroff [12]. The first checklist was used to identify the learning tasks based on the components of intercultural communicative competence while the second checklist was used to identify the learning tasks based on the components of intercultural competence. A checklist was used in this study as it is believed as the most effective way of gathering comparable data structurally. McGrath ensured that checklists can be the effective instrument in gaining the data systematically [13]. Therefore, those are employed in this study.

\section{FINDINGS}

Referring to the goal of learning English for Indonesian students, the in-use textbook should promote intercultural competence besides communicative competence since Indonesian government expects the graduates of senior high school should be able to compete in international domain. Therefore, it is very important to analyze the learning tasks in this textbook which build students' intercultural communicative competence to know to what extent those are presented.

\section{A. Intercultural Communicative Competence in Textbook Learning Tasks}

The following table depicts the the findings of learning tasks which are promoting intercultural communicative competence. There are only four competences of intercultural communicative competence which are covered. They are linguistic competence, discourse competence, interactional competence, and intercultural competence. Sociocultural competence, formulaic competence, and strategic competence are not covered in this textbook.

Based on the table below, it can be deduced that linguistic competence and discourse competence are predominantly presented through learning tasks in the textbook. However, intercultural competece, the key aspect of intercultural communicative competence, is not much promoted. This is because Indonesian government tends to promote local cultures than the target language cultures. 
TABLE I. OVERVIEW OF INTERCULTURAL COMMUNICATIVE COMPETENCE PRESENTED IN TEXTBOOK LEARNING TASKS

\begin{tabular}{|c|c|c|}
\hline $\begin{array}{c}\text { Components of } \\
\text { Intercultural } \\
\text { Communicative } \\
\text { Competence }\end{array}$ & Examples of learning tasks presented & $\begin{array}{c}\text { Learning } \\
\text { Tasks' } \\
\text { Avail- } \\
\text { ability in } \\
\text { Chapter }\end{array}$ \\
\hline $\begin{array}{l}\text { Linguistic: } \\
\text { Ability to apply } \\
\text { knowledge of the } \\
\text { rules of a } \\
\text { standard version } \\
\text { of the language to } \\
\text { produce and } \\
\text { interpret }\end{array}$ & $\begin{array}{l}\text { Match the words with their Indonesian } \\
\text { equivalents. Compare your work with your } \\
\text { classmate's. The first one has been done } \\
\text { for you. } \\
\text { Look at the pictures in the warmer section } \\
\text { again. Make a list of any words (nouns or } \\
\text { verbs) that are related to the pictures. The } \\
\text { words that you find should start with } \\
\text { letters A to Z. } \\
\text { Complete the following sentences using } \\
\text { the words in the box. Remember to use } \\
\text { the correct forms of verbs } \\
\text { Refer back to the text again and find five } \\
\text { sentences written inactive voices. Change } \\
\text { the sentences into passive voices. }\end{array}$ & $\begin{array}{c}1,2,3, \\
4,5,6,7, \\
8,9,10, \\
11,12, \\
13,14, \\
\text { and } 15\end{array}$ \\
\hline $\begin{array}{l}\text { Discourse: } \\
\text { Ability to select, } \\
\text { sequence, arrange } \\
\text { words, structures, } \\
\text { and utterances to } \\
\text { create meaningful } \\
\text { messages or texts }\end{array}$ & $\begin{array}{l}\text { After reading the text, in the chart below, } \\
\text { identify the main idea of each paragraph, } \\
\text { and then write the most important details } \\
\text { in your own words. } \\
\text { Individually, complete the following chart } \\
\text { to find out the structure of the } \\
\text { announcement } \\
\text { Study again the following arrangement of } \\
\text { ideas in a recount text to help you write } \\
\text { the recount text: }\end{array}$ & $\begin{array}{c}1,2,3,4, \\
5,6,7,8, \\
9,10,11, \\
12,13, \\
14, \text { and } \\
15\end{array}$ \\
\hline $\begin{array}{l}\text { Interactional: } \\
\text { Ability to } \\
\text { perform actional } \\
\text { competence and } \\
\text { conversational } \\
\text { competence }\end{array}$ & $\begin{array}{l}\text { Read text } 1 \text { carefully. Pay attention to the } \\
\text { expressions used to congratulate people } \\
\text { (in this case, Alif). Pay attention also to } \\
\text { the responses. } \\
\text { Complete the following table with the } \\
\text { expressions of congratulations and the } \\
\text { responses you find in the preceding } \\
\text { dialogs. } \\
\text { Read the dialog silently and carefully. Pay } \\
\text { attention to the complimenting } \\
\text { expressions and the responses. }\end{array}$ & $\begin{array}{c}1,2 \text {, and } \\
3\end{array}$ \\
\hline $\begin{array}{l}\text { Intercultural: } \\
\text { Ability to interact } \\
\text { and negotiate } \\
\text { with people from } \\
\text { different } \\
\text { countries and } \\
\text { cultures in a } \\
\text { foreign language } \\
\text { equipped with } \\
\text { sufficient } \\
\text { knowledge, } \\
\text { attitudes, skills, } \\
\text { and critical } \\
\text { awareness }\end{array}$ & $\begin{array}{l}\text { Read the following text carefully. While } \\
\text { reading, think about the similarity or } \\
\text { difference between the following texts } \\
\text { with the previous one about Tanjung } \\
\text { Puting National Park. } \\
\text { Imagine that you and your classmates are } \\
\text { all invited to a party and become the } \\
\text { guests there. Think about and use new } \\
\text { identities. For instance, you can pretend } \\
\text { to become your favorite football player, } \\
\text { singer, or scientist, etc. The new identities } \\
\text { make you unfamiliar with each other } \\
\text { because that is the first time you meet. } \\
\text { Pretend as if you were a guide describing } \\
\text { the special peculiarities of the tourism } \\
\text { object. You can also pretend to be a tourist } \\
\text { guide for Tanjung Puting National Park or } \\
\text { Taj Mahal. In that case, make a word web } \\
\text { about Tanjung Putting National Park, or } \\
\text { Taj Mahal, or your own favorite place. } \\
\text { Based on the word web, take turns with } \\
\text { your classmate describing the place. }\end{array}$ & $\begin{array}{c}1,4,5,7 \\
10,12, \\
\text { and } 15 .\end{array}$ \\
\hline
\end{tabular}

\section{B. Components of Intercultural Competence in Textbook Learning Tasks}

The following table is the findings of intercultural competence components promoted in the textbook learning tasks. They are skills of discovery and interaction and critical cultural awareness. However, there are other components which are considered as important as the two components covered in this textbook.

\section{TABLE II. OVERVIEW OF INTERCULTURAL COMPETENCE COMPONENTS} IN THE TEXTBOOK LEARNING TASKS

\begin{tabular}{|c|c|c|}
\hline Components & Examples of Learning Tasks & Chapter \\
\hline $\begin{array}{l}\text { Skills of } \\
\text { Discovery and } \\
\text { Interaction }\end{array}$ & $\begin{array}{l}\text { Imagine that you and your } \\
\text { classmates are all invited to a } \\
\text { party and become the guests } \\
\text { there. Think about and use new } \\
\text { identities. For instance, you can } \\
\text { pretend to become your favorite } \\
\text { football player, singer, or } \\
\text { scientist, etc. The new identities } \\
\text { make you unfamiliar with each } \\
\text { other because that is the first time } \\
\text { you meet. Talk to each other and } \\
\text { introduce yourself } \\
\text { Discuss a popular person (it can } \\
\text { be an inventor, popular people in } \\
\text { the past like actresses, actors, } \\
\text { athletes, etc.) who is going to be } \\
\text { interviewed. The interviewee will } \\
\text { pretend to be this person. }\end{array}$ & $\begin{array}{l}\text { l, } 4,5,7 \text {, } \\
\text { and } 10\end{array}$ \\
\hline $\begin{array}{l}\text { Critical Cultural } \\
\text { Awareness }\end{array}$ & $\begin{array}{l}\text { Read the following text carefully. } \\
\text { While reading, think about the } \\
\text { similarity or difference between } \\
\text { the following texts with the } \\
\text { previous one about Tanjung } \\
\text { Puting National Park. } \\
\text { Read the story about Issumboshi } \\
\text { again. Talk with a partner about } \\
\text { what you would do with the } \\
\text { magic hammer if you were the } \\
\text { princess. Why would you do so? }\end{array}$ & $\begin{array}{l}1,4,5, \\
12, \text { and } \\
15\end{array}$ \\
\hline
\end{tabular}

Based on the table above, it can be identified that attitude, knowledge, and skills of relating and interpreting are not yet covered in the textbook. Accordingly, this textbook does not much promote students' intercultural competence. There should be more learning tasks which concern on the last trend of English language teaching, intercultural communicative competence. Students should not only be rehearsed on their communicative competence, but they should also learn other cultures; both the target language cultures and international cultures, besides they compare and reflact their own cultures. This is expected that students can boost their global awareness of people differences.

\section{DisCUSSIONS}

Learning cultures of a language is a must for language learners since culture and language are inseparable. Language and culture represent two sides of the same coin [14]. This means that cultures of a language should be learnt while ones are learning the language. It also works on learning English. To learn English, students should learn its cultures since many teachers are employing textbooks when they are teaching in the classroom. Thus, the textbook should contain cultural materials which are organized in the learning tasks or activities. 
A. Intercultural Communicative Competence in the Textbook Learning Tasks

Building students' intercultural communicative competence can be generated through learning tasks in the textbook used in the classroom. Based on the findings in the previous section, it can be identified that there are only four competence covered in the textbook. They are linguistic competence, discourse competence, interactional competence, and intercultural competence, while the three competences; sociocultural competence, formulaic competence and strategic competence, are not yet covered. However, all competence should be well included in the textbook through learning tasks in order that students can acquire intercultural communicative competence in the classroom.

\section{1) Linguistic Competence}

This competence is much presented through learning tasks in Bahasa Inggris. There are only three aspects of competence which are covered in the tasks. They are vocabulary, pronunciation, and grammar. Those aspects are considered to build linguistic competence. Canale stated that grammatical competence, or as now called linguistic competence, refers to the knowledge of the language code such as vocabulary, pronunciation, grammatical rules, spelling, etc [15]. However, pronunciation is not well exposed through learning tasks or exercises. There is only one section in each chapter without sufficient exposures as what vocabulary and grammar are performed.

Moreover, this textbook much focuses on the grammatical aspects. Students are provided more materials related to the language structure rather than language use. Meanwhile, communicative competence demands students to be more active in the classroom by using the target language. Students are not enough to do more exposures on the grammatical skills. What the students do is using or practicing the language in daily activities. Therefore, linguistic competence should more build students in applying the knowledge of standard language in communication; not words in isolation and without clear context.

In this textbook, English learnt belongs to inner circle. Kachru states that inner circle refers to the traditional base of English, imposing English as the first language used in daily life [3]. It can be identified from the learning materials which are mostly presented refer to US and UK. Those are displayed through pictures and reading texts.

2) Discourse Competence

This competence is sufficiently presented through learning tasks in this textbook. They mostly assign students to understand and compose a text with certain types such as letter, invitation card, descriptive, narrative, and recount. Canale stated that discourse competence refers to an ability to combine language structures into different types of cohesive text such as poetry, political speech, report, letter, etc. [15]. Thus, those learning tasks can be categorized as discourse competence.

This competence is very important to teach in the classroom because students need to acquire this in real life. They will deal with texts whether in forms of texts, letter, or even speech when they are communicating to each other. They need to understand how to read those things based on the given context. Sentences cannot be separately understood with the situation or condition. Therefore, discourse competence enables students to understand and produce text based on the contexts.
There are 88 learning tasks which are considered as discourse competence in this textbook. This competence is relatively the same presented through learning tasks in number. The forms of learning tasks vary; reading text, answering questions based on text, writing a letter, and writing a text.

3) Interactional Competence

There are three components of interactional competence. They are actional competence, conversational competence, and paralinguistic competence. However, actional competence is predominantly performed in this textbook. It enables students to perform common speech acts and speech act sets in the target language involving interaction such as expression of regret, apology, blaming, complaint, etc. [16]. The learning tasks which are promoting students' interactional competence presented in this textbook are expressions of congratulating, complimenting, intention, and introduction. These learning tasks are necessary for students as they need to express their feelings and thoughts through those expressions.

Moreover, this textbook shows how to use the expression in conversation. It is shown through examples then students are asked to practice in a role play. It exposes students to do much better in a real communication and interaction. Thus, students are at first using the model of conversation provided in the textbook then they are arranging and using the expression in a given context.

4) Intercultural Competence

In this textbook there are only small number of learning tasks which are concerned on building students' intercultural competence. It is considered as a small extent. There are some learning tasks which contain cultural materials. Yet, they do not promote intercultural competence. They are only presenting Indonesian cultures in one side. The learning tasks or activities do not give students' opportunity to rehearse their competence by comparing or contrasting among the target cultures, International cultures, and source cultures (Indonesian cultures). Therefore, those cultural materials cannot be categorized as building intercultural competence.

Intercultural competence should be taken into account in English language teaching nowadays as the trend development of English language teaching is now shifted from communicative competence to intercultural communicative competence as stated by $\mathrm{Fu}$ in Xiao [1]. Therefore, it should be covered in the teaching materials (textbook) in medium or large extent. Yet, this textbook, Bahasa Inggris, does not concern on the issue. It will later affect students' competence.

As the results, students will be incapable of communicating effectively with people in different cultures. Lange argues that misunderstandings and critical incidents are not caused by a lack of language skill, but they are frequently initiated by cultural differences, i.e.; lack of intercultural competence. It shows that intercultural competence is very importantly addressed to students since communicative competence does not guarantee the successful communication with native speakers in real world Lange [17].

Referring to the learning tasks which are performed in textbook Bahasa Inggris, intercultural competence is seemingly put aside. It is proven that those are not even presented in every chapter as what the ones of communicative competence are. It implies that this textbook is focused on students' communicative competence because intercultural competence is covered in a small extent. However, the government expects that the Indonesian students can compete 
in the international domain. They should then be capable of communicating with people in different cultures. Thus, intercultural competence should be highly covered in the teaching materials, in this case is textbook, in order that the goals of Indonesian government are in line with the trend of English language teaching nowadays.

\section{B. The Components of Intercultural Competence in the Textbook Learning Tasks}

This textbook covers the two components of intercultural competence in which it is in a very small extent. It is insufficient to build students' intercultural competence through the learning tasks which are presented in the textbook. Teacher should develop the learning tasks or even find other references and learning activity to promote this competence in the classroom. Here are the discussions of the component of intercultural competence found in the textbook.

1) Skills of discovery and interaction

There are some learning tasks which are promoting students' skills of discovery and interaction in this textbook. Through the learning task, skills of discovery and interaction can be built since it gives students' chance to operate their knowledge about certain issues, in this case is Tanjung Puting National Park, Taj Mahal, or other places. Byram stated that skills of discovery and interaction enables students to acquire new knowledge of a culture and cultural practices and operate the knowledge, attitude, and skills in communication and interaction [18].

Afterwards, they can use the knowledge along with attitudes and skills under the constrains of real-time communication and interaction. Because students are asked to pretend to be a tourist guide for places which can be in overseas, it leads students to upgrade the knowledge about how foreigners perceive the places and behave upon them. Therefore, this task is classified into skills of discovery and interaction; students should discover certain issues for communication and interaction.

\section{2) Critical Cultural Awareness}

There are some learning tasks which are considered as promoting students' critical cultural awareness in this textbook. Byram [18] stated that critical cultural awareness enables students to identify and interpret values of documents and events explicitly and implicitly.

One of the tasks above assigns students to read text 1 which is about Tajung Puting National Park and text 2 which is about Taj Mahal. Afterwards, they are assigned to compare those texts with text entitled Niagara Falls and find out the similarities among the three text. It gives students' opportunity to evaluate the three texts which are cultural products from three different countries. Thus, this task can build students' intercultural competence for critical awareness.

This component of intercultural competence is much found than other components presented through learning tasks in this textbook. However, there should be more learning tasks which promote students' critical cultural awareness in the textbook since this component of intercultural competence is very important for students in real communication and interaction. They need to be aware how they perceive cultural differences and how they take an action toward the differences. Moreover, they will understand that cultural differences do not really matter and are normal. Thus, they will not perceive other people as strangers.

\section{CONCLUSION}

Learning tasks in this textbook do not promote intercultural communicative competence. Linguistic competence and discourse competence are predominantly covered. It seems that intercultural competence is put aside since the indonesian government much concerns on local wisdoms or cultures. Therefore, it is suggested that the textbook should present more intercultural learning tasks which can promote students' intercultural communicative competence as the last trend in English language teaching. Both communicatve and intercultural competence should be proportionally promoted and intergrated through learning tasks in the textbook.

\section{References}

[1] J. Xiao, "Cultural content of an in-use EFL textbook and major students' attitudes and perceptions towards culture learning at Jiangxi University of Science and Technology, China,"," Unpublished MA thesis), Jiangxi University of Science and Technology, Jiangxi: China. Published by European Centre for Research Training and Development UK (www. eajournals. org), 2010.

[2] F. L. Siregar, "In pursuit of intercultural communicative competence: An investigation into English language policy and practices at a private university in Indonesia," 2016.

[3] B. Kachru, "Standards, codificationandsociolinguisticrealism: theEnglishlanguageintheoutercircle. InR. Quirk\& HG Widdowson," Englishintheworld-Teachingandlearning the language and literature, 1985.

[4] L. Sercu, "Autonomous learning and the acquisition of intercultural communicative competence: Some implications for course development," Language culture and curriculum, vol. 15, pp. 61-74, 2002

[5] J. C. Richards, Curriculum development in language teaching: Ernst Klett Sprachen, 2001.

[6] D. Kaiser, Pedagogy and the practice of science: Historical and contemporary perspectives: MIT Press, 2005.

[7] B. Tomalin and S. Stempleski, Cultural awareness: Oxford University Press, 1994.

[8] C. Edwards and J. R. Willis, Teachers exploring tasks in English language teaching: Springer, 2005.

[9] R. Kjartansson and L. Skopinskaja, "Incorporating intercultural communicative competence in language teacher education," European Centre for Modern Languages Council of Europe Publishing, Strasbourg, 2003.

[10] D. Ary, L. C. Jacobs, and C. K. Sorensen, Introduction to research in education, 8th ed. Belmont, CA: Wadsworth, 2010.

[11] N. Verhelst, P. Van Avermaet, S. Takala, N. Figueras, and B. North, Common European Framework of Reference for Languages: learning, teaching, assessment: Cambridge University Press, 2001.

[12] D. K. Deardorff, "Identification and assessment of intercultural competence as a student outcome of internationalization," Journal of studies in international education, vol. 10, pp. 241-266, 2006.

[13] I. McGrath, Materials Evaluation and Design for Language Teaching Edinburgh Textbooks in Applied Linguistics: Edinburgh University Press, 2002

[14] D. Nault, "Going global: Rethinking culture teaching in ELT contexts," Language, Culture and Curriculum, vol. 19, pp. 314-328, 2006.

[15] M. Celce-Murcia, Z. Dörnyei, and S. Thurrell, "Communicative competence: A pedagogically motivated model with content specifications," Issues in Applied linguistics, vol. 6, pp. 5-35, 1995.

[16] M. Celce-Murcia, "Rethinking the role of communicative competence in language teaching," in Intercultural language use and language learning, ed: Springer, 2008, pp. 41-57.

[17] K. Lange, "Perspective on intercultural competence. A textbook analysis and an empirical study of teachers' and students' attitudes," Thèse de Master: Université Libre de Berlin., Allemagne.

[18] M. Byram, Teaching and assessing intercultural communicative competence: Multilingual Matters, 1997. 